\title{
Aspects of Habitat Use by Birds during Spring in Natural Forests and Non-Native Plantation Forests in the Lower Siret Meadow (Eastern Romania)
}

\author{
Matei-Ionut DRAGOMIR ${ }^{1,2,{ }^{*}}$, Alina DRAGOMIR ${ }^{1}$, Dumitru MURARIU²
}

\begin{abstract}
${ }^{1}$ Association for Biological Diversity Conservation, Ion Creangă no. 12, 620083, Focşani, Romania. ${ }^{2}$ University of Bucharest, Faculty of Biology, Splaiul Independenței no.91-95, Bucharest, 5, Romania. *corresponding author, e-mail: matei.dragomir@acdb.ro
\end{abstract}

\begin{abstract}
The Lower Siret Meadow forest habitats have been altered from natural structure because of commercial forestry operations, activities that are defining the forest management from previous decades. Afforestation programs aimed to test the introduction of exotic tree species in order to increase wood production and to reduce harvest time intervals. These commercial influences reflect in the decrease of natural forest areas, aspect that could influence the birds presence. Studies on the ecological impact of plantations on birds are scarce, and no studies were found regarding this aspect in the region. Using six different sample areas both in native and non-native tree plantations, we investigated how bird presence is influenced by the support capacity offered by both natural or non-native plantations and which vegetation variables are related to our results. We compared the data from the surveyed areas to relate birds presence and dependence on certain characteristics of the habitats. Our results pointed out that species diversity is higher in natural forests with local tree species and vegetation characteristics like forest canopy density, shrub coverage, and herbaceous layer.
\end{abstract}

Key words: forests, habitats, birds, migration, forest management, Lower Siret Meadow

\section{INTRODUCTION}

In the Lower Siret Meadow, like in many other similar floodplains in the region, natural forests are heavily influenced due to commercial forestry operations made in order to shorten the production cycles by replacing native species with hybrid and non-native ones (Munteanu et al., 2009), the same situation as in other places in Europe (Steiger et al., 2005; Martin-Garzia et al., 2013). In many cases, plantation strategies involving clear-cut techniques together with short rotation times and removing old or dead trees, decrease the biodiversity associated natural forests (Green, 2001; Martin et al., 2006; Fedrowitz et al., 2014). Most of the woodland area in the study is covered by forest plantations and the naturally regenerated trees are subject to human activity for the selection of species for commercial reasons. Pure stands of black locust (Robinia pseudoacacia) or hybrid poplar (Populus $x$ canadensis) represents a limiting factor for site biodiversity, monocultures being slightly less diverse in bird community presence than mixed plantations (Sweeney et al. 2010), and providing less ecosystem goods and services (Thompson et al., 2009).

As the overall biodiversity in forest landscapes cannot be measured and quantified directly (Martin-Garcia et al., op. cit.), ecological indicators can be used to measure the specific terms and trends of concern (Noss, 1999). In these conditions, the ecological impact of the economically oriented forest management can be illustrated using birds as indicators, the ecology, abundance, and distribution of birds being 
sensitive to environmental conditions (Canterbury et al., 2000; Gregory and Strien, 2010). In order to give a balanced view of the avifauna using the forests with native tree species and monocultures of hybrid or alien species, we focused the study on assessing how bird diversity changed according to the habitat composition in six different forest habitats. We hypothesized that structural complexity of natural forest habitats can explain the higher values for birds and that bird presence depends mainly on variables associated with natural habitats.

Maintaining the forest ecological integrity requires silvicultural measures which take into consideration a more "close-to-nature" approach (Schütz, J.P. 1999; Dorren et al., 2004; Bauhus et al., 2013) aiming ai an emphasis on structural diversity and small-scale variability, deployment of mixed species and natural regeneration (Puettmann et al., 2015). Therefore, it is proposed that both forest and protected areas management should follow an adaptative approach in decision making (Dorren et al., 2004), but effectiveness of adaptative management depends on how well objectives are set according to the natural system under management (Smith et al., 2013). Therefore, in the following sections we hope to provide a basis for managers about some vegetation attributes that influence the bird presence. At the same time, we provide a primary set of data about the current status of avifauna use of natural forests and plantations in this region.

\section{MATERIAL AND METHODS}

\section{Study sites}

The study has been carried out in the Natura 2000 site ROSPA0071 Lower Siret Meadow (Eastern Romania), in two natural reserves (Fig. 1): Black Forest Natural

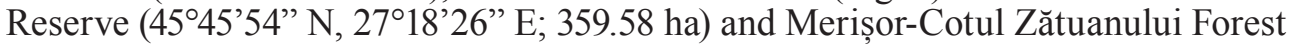

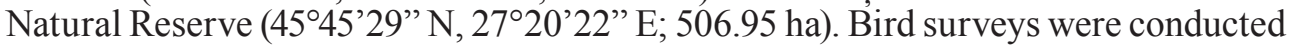
in 6 different forest habitat types, both with native and introduced species: (Populus nigra);

T1 - Native poplar forest: White Poplar (Populus alba) and Black Poplar

T2 - Acacia plantation: Black Locust (Robinia pseudoacacia);

T3 - Hybrid poplar plantation: Canadian poplar (Populus $x$ canadensis);

T4 - Oak: mainly Oak (Quercus robur), with few individuals of Narrowleaf Ash (Fraxinus angustifolia), Ash (Fraxinus excelsior), Elm (Ulmus minor) and Maple (Acer campestre); cordata);

T5 - Linden: Silver Linden (Tilia tomentosa) and Little-leaf Linden (Tilia

T6 - Pine: Black Pine (Pinus nigra) plantation with scattered individuals of Black Locust (Robinia pseudoacacia) invasive extended.

\section{Survey methods}

Data on bird species and community information were obtained by conducting transect counts in six different $500 \mathrm{~m}$ transects, each of them with the same habitat type as specified in the previous section (T1-T6 transects). The observations were made on both sides of the transects on $25 \mathrm{~m}$ strips (Gregory et al., 2004; Horton et al., 2016). To increase accuracy in calculating distance, all sample strips were marked at the outer edges with a color band at every $50 \mathrm{~m}$.

Sample areas were selected from 6 different forest habitats according to the availability of these surfaces, forest practices applied in the region involved the use of small areas for plantations. Bird counts were carried out three times during the spring 


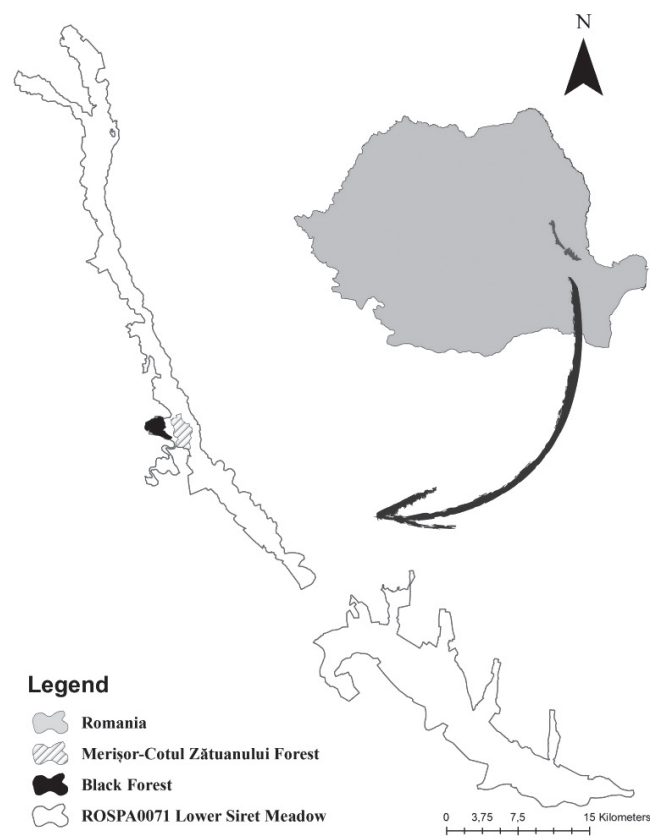

Fig. 1 - study area

migration and breeding season (late March, late April and late May). Observations took place in mornings (approximate 5.00 - $9.00 \mathrm{am}$ ). All bird species using the habitat (sitting or displaying over the transect) were taken into consideration. Birds detected outside the 50-meter strip were not included in the analyzes.

\section{Data analysis}

Vegetation variables were estimated in each sample plot. The canopy cover was assessed using a sighting tube with a single central cross-wire (Goodenough and Goodenough, 2012). At each $2 \mathrm{~m}$ point along the same transect, we observed directly overhead through the tube and recorded whether the crosshair intercepted overhead foliage (Ganey and Block, 1994). The result of each individual measurement was recorded as " 1 " if the crosshair intercepted foliage and as " 0 " otherwise (Subasinghe et al., 2014). The percentage of herbaceous and shrub layers was visually estimated (Dethier et al., 1993; Simons et al., 2006; Damgaard, 2014).

Vegetation attributes (canopy, shrub, and herbaceous layer) were compared using paired t-test (Simons et al., op. cit.).

The density of birds was estimated by dividing the count $n$ by the covered area, $a=2 \mathrm{wL}$, where $\mathrm{w}$ is the strip width and $L$ is the total length of transects (Bukland et al., 2008). Table 1 presents density ( $\mathrm{D}^{\wedge}$ ) as a total number of individuals per hectare. To test for the difference between sites, a Kruskal-Wallis test was performed (Rija et al., 2015; MacGregor-Fors et al., 2012) and one-way ANOVA (Subasinghe et al., op. cit.). Structural characteristics were calculated for each forest habitat and communities were evaluated using values like species richness, number of individuals, Simpson Diversity Index $\left(1-D\right.$, where $D=\sum(n / N)^{2}$, with $n=$ total individuals from one species and $\mathrm{N}=$ total individuals identified $)$, Shannon-Wiener Index $\left(\mathrm{H}^{\prime}=-\sum \mathrm{p}_{\mathrm{i}} \ln \mathrm{p}_{\mathrm{i}}\right.$, where 
Structural characteristics of bird communities in six forest types from the Lower Siret Meadow in March, April and May

\begin{tabular}{cccccccc}
\hline & & $\hat{\mathbf{D}}$ & $\mathbf{S}$ & $\mathbf{I}$ & $\mathbf{1 - D}$ & $\mathbf{H}$ & $\mathbf{J}$ \\
\hline \multirow{3}{*}{ T1 (Poplar) } & 03 & 8.5 & 11 & 42 & 0.855 & 2.122 & 0.759 \\
& 04 & 6.8 & 11 & 34 & 0.844 & 2.080 & 0.727 \\
& 05 & 8.6 & 15 & 43 & 0.866 & 2.377 & 0.718 \\
\hline \multirow{3}{*}{ T2 (Acacia) } & 03 & 3.2 & 6 & 16 & 0.703 & 1.429 & 0.695 \\
& 04 & 3.6 & 8 & 19 & 0.792 & 1.782 & 0.742 \\
& 05 & 3.8 & 10 & 19 & 0.858 & 2.129 & 0.840 \\
\hline \multirow{3}{*}{ T3 (Hybrid poplar) } & 03 & 1.6 & 4 & 8 & 0.656 & 2.213 & 0.840 \\
& 04 & 3.4 & 5 & 18 & 0.518 & 1.051 & 0.571 \\
& 05 & 3 & 8 & 15 & 0.782 & 1.807 & 0.761 \\
\hline \multirow{3}{*}{ T4 (Oak) } & 03 & 5.8 & 8 & 29 & 0.811 & 1.813 & 0.766 \\
& 04 & 5.6 & 12 & 28 & 0.826 & 2.126 & 0.698 \\
& 05 & 6.2 & 14 & 31 & 0.884 & 2.416 & 0.800 \\
\hline \multirow{3}{*}{ T5 (Linden) } & 03 & 3.2 & 5 & 16 & 0.773 & 1.527 & 0.921 \\
& 04 & 3.2 & 6 & 16 & 0.671 & 1.386 & 0.666 \\
& 05 & 4.2 & 7 & 21 & 0.725 & 1.538 & 0.664 \\
\hline \multirow{3}{*}{ T6 (Black Pine) } & 03 & 1.6 & 3 & 8 & 0.531 & 0.900 & 0.820 \\
& 04 & 3.8 & 6 & 19 & 0.703 & 1.466 & 0.721 \\
& 05 & 3.6 & 5 & 18 & 0.753 & 1.480 & 0.878 \\
\hline
\end{tabular}

Species Density (D^); Species richness (S); number of individuals (I); Simpson Diversity Index (1-D); ShannonWiener Index (H'); Species Evenness $\left(\mathrm{J}^{\prime}\right)$.

$\mathrm{p}_{\mathrm{i}}$ is the proportion of individuals found in species i) and Species Evenness $\left(\mathrm{J}^{\prime}=\right.$ $\mathrm{H}^{\prime} / \mathrm{H}_{\text {max }}^{\prime}$, where $\mathrm{H}^{\prime}$ is the number from the Shannon diversity index and $\mathrm{H}_{\text {max }}{ }^{\text {is }}$ ise maximum value of $\mathrm{H}^{\prime}$ ).

To evaluate the relationship between bird species richness and vegetation variables, we performed Pearson's correlation test (Subasinghe et al., op. cit.).

We performed one-way ANOVA followed by the Tukey test to compare species richness and relative abundance (number of individuals per sample transect) in natural forests and plantations (Subasinghe et al., op. cit.).

For differences between communities in the sample plots, we used the BrayCurtis test, with measures calculated only for the species found in all surveyed transects. Bird community dominance index (proportion of the two most abundant species in the community) was also computed. 2001).

The PAST software was used to perform statistical analysis (Hammer et al.,

\section{RESULTS}

\section{Bird ecological structural characteristics}

In the six different surveyed forest habitats, 31 bird species were identified, $67.74 \%$ of them being found in more than 1 forest habitat type. Common Chaffinch 
(Fringilla coelebs), Common Blackbird (Turdus merula), Common Starling (Sturnus vulgaris), Great Tit (Parus major) and Song Thrush (Turdus philomelos) were the species with the highest habitat amplitude and were found in all sample plots. These species dominate the communities from T2, T3 and T6 transects (Fig. 2) with nonnative tree species plantations, showing the highest value in T6 $\mathrm{D}=0.47(\mathrm{D}=1$ Simpson index).

Species richness ranged between 3 (T6 transect in March) and 15 (T1 transect in May). Native species forests (T1, T4, T5 transects) presented an increased species richness compared to non-native ones (T2, T3, T6) (Fig. 2).

Based on the Shannon-Wiener Index, the species diversity (mean of 3 visits), as shown in Fig. 3, was highest (2.193) in T1 (poplar) where richness is also at a higher level, and lowest (0.982) in T6 (black pine). The difference between mean values of this index for bird species diversity in native and non-native forests can not be considered statistically significant (t-value is $1.324, \mathrm{p}>0.05)$, thus ANOVA on Shannon-Wiener index revealed differences between the means $(\mathrm{F}=3.212, \mathrm{p}=0.045)$.

Comparing species density $\left(\mathrm{D}^{\wedge}\right)$ between transects, we found a significant difference between sample medians (Kruskal-Wallis $\chi^{2}=12.91, \mathrm{H}_{\mathrm{c}}=13.01, \mathrm{p}=0.02$ and one-way ANOVA $\mathrm{F}=19.97, \mathrm{df}=5.39, \mathrm{p}=0.001)$. When comparing the same density between sample plots, we observed a greater number of species (5.79 mean) in native species forest than in non-native plantations (3.07 mean), t-test revealed a statistical significant difference (t-value $=3.72, \mathrm{p}<0.05)$.

Using the species evenness $\left(J^{\prime}\right)$ values, we can quantify the bird communities in 6 sample surfaces as evenly distributed, with no significant difference between sample medians (Kruskal-Wallis $\chi^{2}=1.68, \mathrm{H}_{\mathrm{c}}=1.68, \mathrm{p}=0.89$ and one-way ANOVA $\mathrm{F}=0.35, \mathrm{df}=5.12, \mathrm{p}=0.86)$ and same result when comparing natural and non-native plantations ( $\mathrm{t}$-test: $\mathrm{t}=-0.669, \mathrm{p}>0.05)$.

We compared the Simpson Diversity Index (1-D) from all sample plots (Fig. 4). Kruskal-Wallis test demonstrates a significant difference between sample medians $\left(\chi^{2}=4.30, \mathrm{H}_{\mathrm{c}}=4,31, \mathrm{p}=0.03\right)$, also usig t-test, the difference between native and nonnative plantations can be considered statistically significant (t-value is $2.36, \mathrm{p}<0.05$ ).

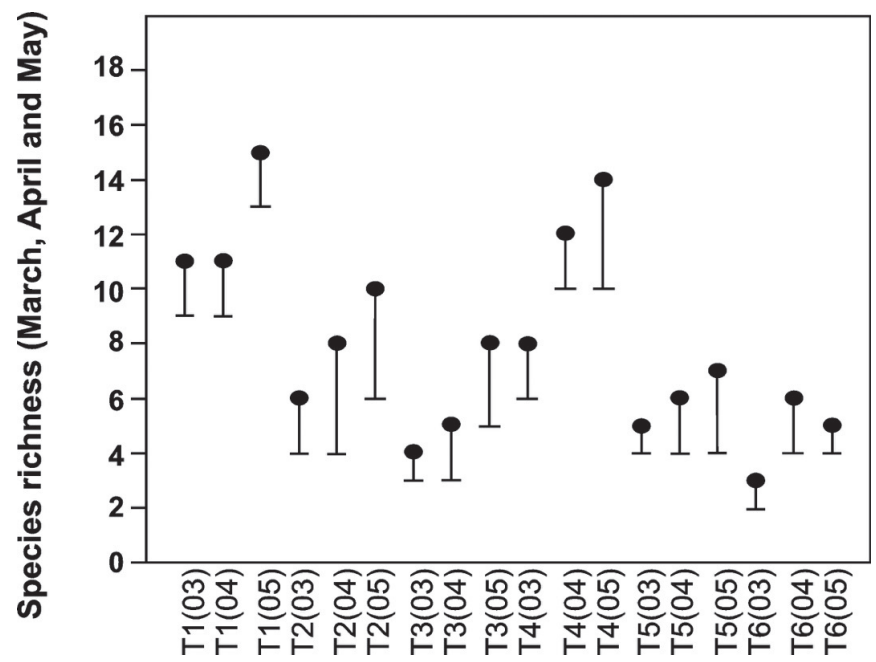

Fig. 2 - Species richness in March (03), April (04) and May (05) for each sample plot. 


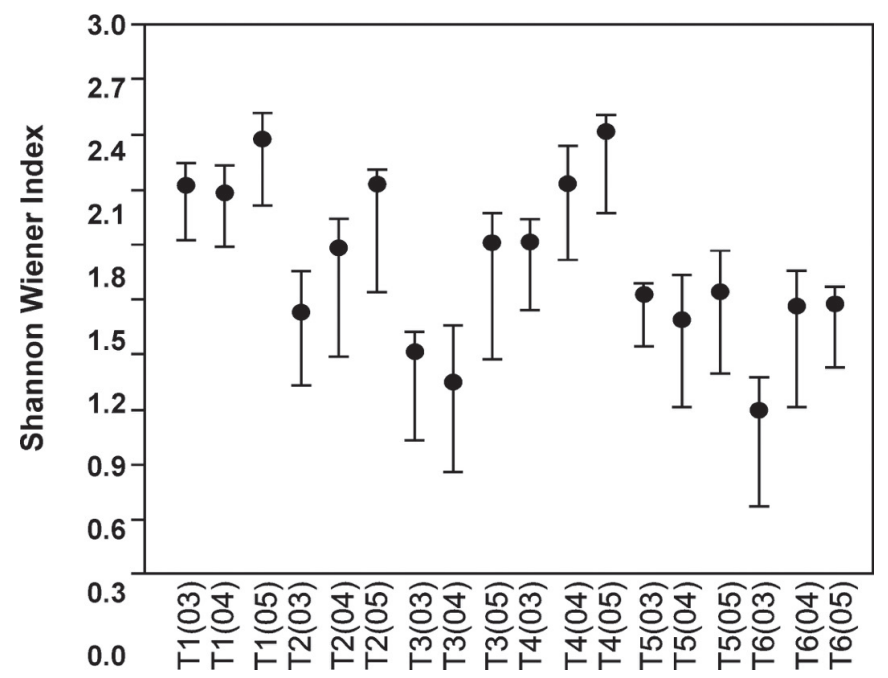

Fig. 3 - Shannon-Wiener Index in March (03), April (04) and May (05) for each sample plot.

\section{Bird presence in relationship with vegetational structural attributes}

Vegetation structural attributes showed no differences between native forests and silviculturally managed plantations. Canopy cover density was the lowest (40 $50 \%$ ) in the T2 transect (Acacia) and the highest $(95-100 \%)$ in T6 transect (Black Pine). No difference was observed in the comparison of canopy cover (paired t-test value $0.31, p>0.05$ ), undergrowth herbaceous layer (paired t-test value $0.62, p>$ 0.05 ), and shrub coverage (paired t-test value $0.77, \mathrm{p}>0.05$ ).

Bird species richness showed a negative linear relationship between species richness and canopy coverage (Pearson's correlation coefficient $r=-0.10$ ). Species presented a positive linear relationship with the herbaceous layer, but the relationship between these variables is weak (Pearson's correlation coefficient $r=0.31$ ). From the vegetation attributes, a moderate positive correlation was identified with shrub coverage (Pearson's correlation coefficient $r=0.54$ ).

Bray-Curtis index value for species found in all transects $(0.69)$ points dissimilarity across sample plots (Fig. 5a), the same test performed on bird presence in native and non-native forests (Fig. 5b) has even a higher value (0.78), non-native forest plantations being used by fewer individuals from these species.

The community dominance index was considerably high in non-native plantations due to a low number of species (Fig. 6). This index was the lowest in the T1 (poplar) and T4 (Oak) transects, indicating that in these sample plots, the community structure is without extreme dominance, also all sample surfaces had a lower value in May (05) due to completed spring migration, only breeding species being present at this date.

\section{DISCUSSION}

Habitat use by birds during spring in native and non-native forests

This study presents the bird communities as well as the structural characteristics and the relationship between some vegetation attributes which can be associated with the presence of birds. Additionally, the study results suggest that native forests 


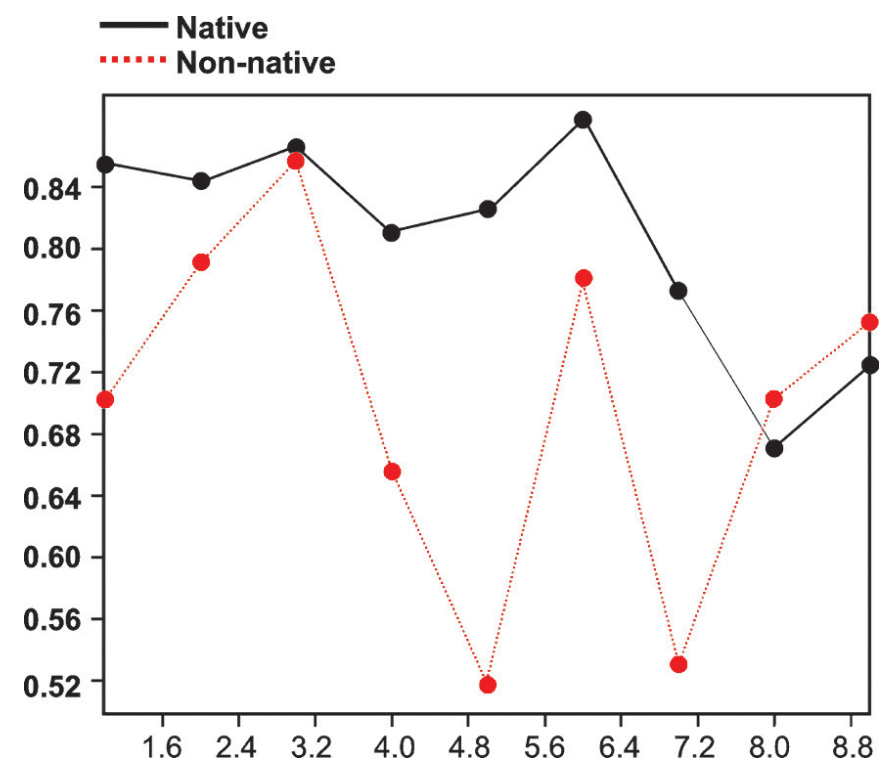

Fig. 4 - Simpson Diversity Index (1-D) of birds species in habitats with native and non-native tree species transects.

are used by more bird species compared to non-native tree plantations, but shrub vegetation and open spaces presence in all forest types can contribute to the increase of bird presence.

Our results are limited, we only sampled the transects in one year, changes in avian populations can occur over the years due to both regular and irregular fluctuations (Temple and Wiens, 1989). Also, we only sampled areas that were relatively close to each other, and because the areas were forestry managed until recently, availability of compact forest habitats was scarce, that is why we were forced to use transects starting and ending along forest edges, ecotone areas with different bird presence (Poprach, 2015).

The exotic species plantations included in this study show differences in bird communities compared to the natural forests, but lack of human interventions due to protection status obtained in 2005 (Natural Reserve), create a favourable framework for the development of natural forest attributes which may represent important determinants for biodiversity. The more complex is the landscape mosaic, the presence and detection of birds is expected to vary (Melles et al., 2003).

Hybrid Poplar and Black Pine plantations had the lowest values for birds, lack of shrub vegetation and poor understory herbaceous coverage suggests that birds may be constrained by the absence of suitable nest sites (Bergner et al., 2014). Also compared to natural species forest stands, exotic species plantations supported lower values for the analyzed variables.

The natural/exotic forest factor alone has a rather low explanatory power for the observed differences, our results point that vegetation structure attributes are the most important explanatory variables. The relationship between understory shrub vegetation coverage, species richness, and Simpson's diversity Index suggest that the ecological state of the forest exerts the greatest influence on the bird communities 


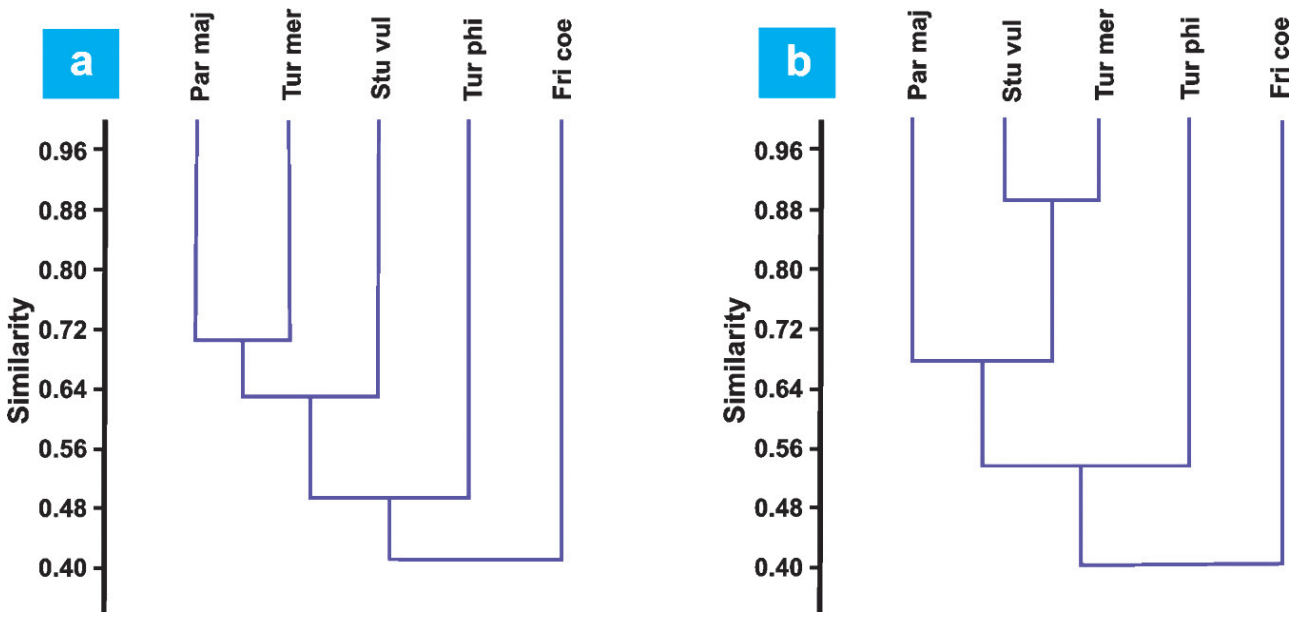

Fig. 5 - Bray-Curtis Index value for same species across all sample plots (a) and native/non-native forests (b): (Par maj-Parus major; Tur mer-Turdus merula; Stu vul-Sturnus vulgaris; Tur phi-Turdus philomelos; Fri coe-Fringilla coelebs).

(Sweeney et al., op. cit.), shrubs providing nesting and foraging sites in both native and exotic forest plantations. As an example, among the forests plantations with nonnative species, transect 2 (Acacia plantation) has a higher Simpson Diversity Index compared to other transects (both native and non-native), this may be explained by vegetation structural attributes in each transect (small shrub percentage cover is found on this transect, compared with same vegetation attribute almost absent in the natural linden forest, for example).

Comparing the bird presence and herbaceous layer coverage, a weak positive linear relationship was observed, but there is more likely that species richness could be related to the availability of open space, herbaceous layer being more developed in open spaced zones (Gil-Tena et al., 2007; Ranjit Daniels et al., 1992).

The lower number of species encountered in native forest habitat T5 (linden), where the canopy density is $80-100 \%$, compared to T1 (poplar) transect with 70 $-80 \%$ density, and high presence of generalist species, can be explained by the influence of the forest canopy density, closed forest canopies being a factor which diminishes species richness (Gil-Tena et al., 2007). Another possible explanation for higher species richness could be given by the presence of open patches in tree cover for T1 transect (Ranjit Daniels et al., 1992), and high shrub coverage (Graham et al., 2014), this can justify the number of species also in T2 transect (acacia) where shrub vegetation is present.

Higher number of birds were observed at the end of T4 transect / start of T5 transect, near an elongated clearing in forest, open space being kept this way because of an electric power line crossing the forest. Higher values could be explained by the presence of this open space that allows light penetration and enhances plant diversity (Smith et al., 2007).

Although bird species richness showed a negative linear relationship with the canopy coverage, on T4 transect (oak), the species richness value (mean of 3 visits) was second highest, aspect that can be explained by the presence of three bird species (Goldcrest-Regulus regulus, Thrush nightingale - Luscinia luscinia and Tree 


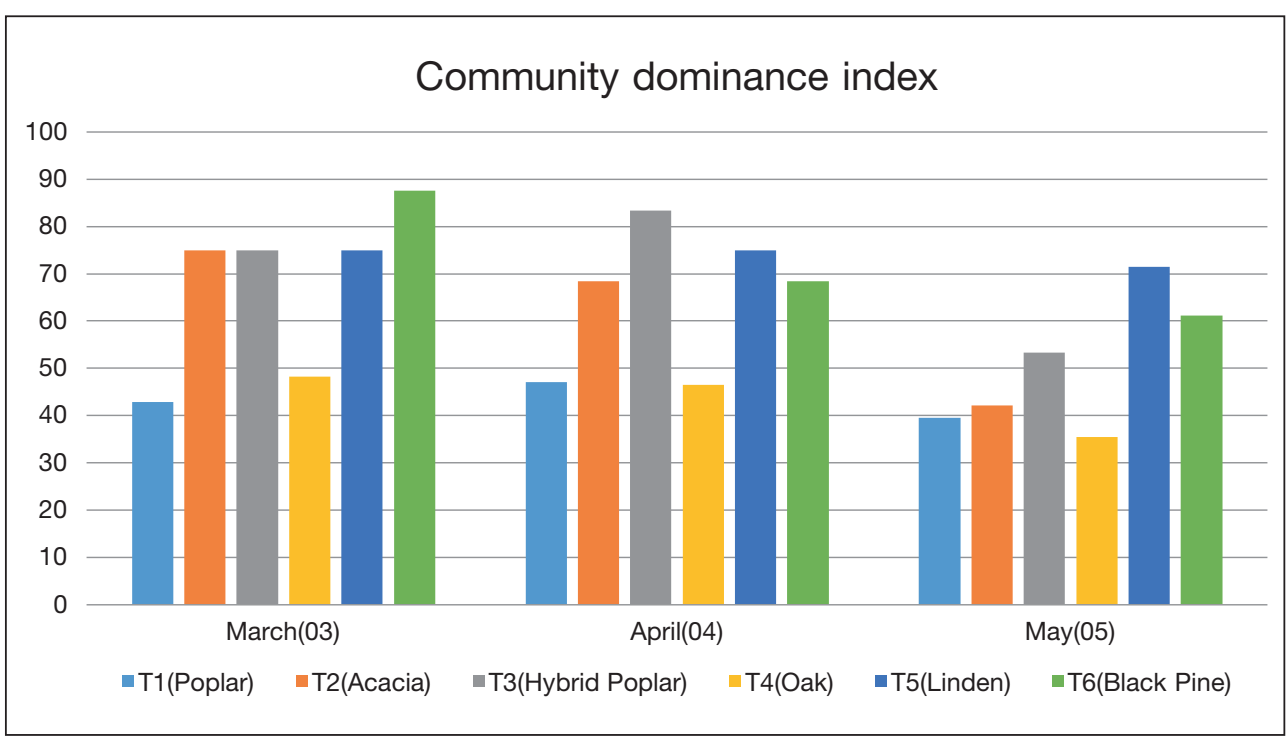

Fig. 6 -Community dominance index across sample plots in all field visits.

pipit - Anthus trivialis) at the end of transect, in the ecotone zone, where the number of bird registrations can be higher compared to inside closed forest (Poprach, op. cit.).

Ecological structural characteristics in the six different habitats surveyed point that bird presence is in a relationship with the vegetational structural attributes, but also resource level could be a limiting factor of habitat support for various species (Bergner et al., op. cit.). For example, the richness of invertebrates can be associated with the different tree species or openness in the forest canopy (Horak et al., 2014).

Considering the species evenness values, the bird communities can be regarded as evenly distributed, but the data may be more closely linked to habitat complexity or heterogeneity (Symonds and Johnson, 2008), so this may be why we have close to uniform species communities in both natural forests and plantations.

Because all sample plots are in forest habitats, it can not be considered that species found in only one plot are habitat specialist, they can rather be more or less dependant on certain characteristics of the habitat (like Red-backed Shrike - Lanius collurio found only in $\mathrm{T} 1$ transect near forest edge in a zone with high shrubs density) or species occasionally present (Ural Owl-Strix uralensis seen only once in T4 transect).

\section{Management implications}

Potential declines in common birds are important as birds play vital roles in the structuring and functioning of ecosystems and declines of their numbers will likely reduce ecosystem processes and services (Inger et al., 2014). The assessment of forest attributes as biodiversity determinants and species assembly structure is needed for suitable management measures and conservation targets in forest stands (Bergner et al., op. cit.).

All forest stands are even-aged, and mostly monospecific, also lying deadwood is a rare element in all forests because it is collected by local communities to be used as firewood. 
Tree species alone, although is a defining criterion for the forest habitats, does not explain the bird presence. Natural habitats can reflect the abundance of birds or domination of species. At present, these forests are excluded from any kind of forestry management, but in the past, they were considered production forests so the management was economically oriented. Future interventions should take vegetation structure into account as it seems important for bird presence, habitat management in forest stands should be targeted depending on species particular requirements as they can be critical for some bird species (Camprodon and Brotons, 2006).

\section{REFERENCES}

ARCHAUX, F., H. MARTIN (2009) Hybrid poplar plantations in a floodplain have balanced impacts on farmland and woodland birds. Forest ecology and management 257 (6): 1474-1479.

BAUHUS, J., K. J. PUETTMANN, C. KÜHNE (2013) Close-to-nature forest management in Europe: does it support complexity and adaptability of forest ecosystems? Managing forests as complex adaptative systems: building resilience to the challenge of global change. Routledge, New York, pp. 187-213.

BERGNER, A., M. AVCI, H. ERYIGIT, N. JANSSON, M. NIKLASSON, L. WESTERBERG, P. MILBERG P. (2014) Influences of forest type and habitat structure on bird assemblages of oak (Quercus spp.) and pine (Pinus spp.) stands in southwestern Turkey. Forest Ecology and Management 336: 137-147.

BUCKLAND, S. T., S. J. MARSDEN, R. E. GREEN (2008) Estimating bird abundance: making methods work. Bird Conservation International 18: 91-108.

CAMPRODON, J., L. BROTONS (2006) Effects of undergrouth clearing on the bird communities of the Northwestern Mediterranean Coppice Holm oak forests. Forest Ecology Management 221: 72-82.

CANTERBURY, G. E., T. E. MARTIN, D. R. PETIT, L. J. PETIT, D. F. BRADFORD (2000) Bird communities and habitat as ecological indicators of forest condition in regional monitoring. Conservation Biology 14: 544-558.

DAMGAARD, C. (2014) Estimating mean plant cover from different types of cover data: a coherent statistical framework. Ecosphere 5(2): 20. Available at: http://dx.doi.org/10.1890/ES13-00300.1 (accessed on 02.03.2016).

DETHIER, M. N., E. S. GRAHAM, S. COHEN, L. M. TEAR (1993) Visual versus random-point percent cover estimations: 'objective' is not always better. Marine Ecology Progress Series 96: 93-100.

DORREN, L. K. A., F. BERGER, A. C. IMESON, B. MAIER, F. REY (2004) Integrity, stability and management of protection forests in the European Alps. Forest Ecology and Management 195: 165-176.

FEDROWITZ, K., J. KORICHEVA, S. C. BAKER, D. B. LINDENMAYER, B. PALIK, R. ROSENVALD, W. BEESE, J. F. FRANKLIN, J. KOUKI, E. MacDONALD, C. MESSIER, A. SVERDRUPTHYGESON, L. GISTAFSSON (2014) Can retention forestry help conserving biodiversity? A meta-analysis. Journal of Applied Ecology 51: 1669-1679.

GANEY, J. L., W. M. BLOCK (1994: A comparison of two techniques for measuring canopy closure. Western Journal of Applied Forestry 9(1): 21-23.

GIL-TENA, A., S. SAURA, L. BROTONS (2007) Effects of forest composition and structure on bird species richness in an Mediterranean context: Implications for forest ecosystem management. Forest Ecology and Management 242: 470-476.

GRAHAM, C. T., M. W. WILSON, T. GITTINGS, T. C. KELLY, S. IRWIN, O. F. M. SWEENEY, J. O'HALLORAN (2014) Factors affecting the bird diversity of planted and semi-natural oak forests in Ireland. Bird Study 61: 309-320.

GREEN, T. (2001) Ecological and socio-economic impacts of close-to-nature forestry and plantation forestry: a comparative analysis. Proceedings of the Scientific Seminar of the 7th Annual EFI Conference. Instituto Superior de Agronomia, Lisbon, Portugal.

GREGORY, R. D., D. W. GIBBONS, P. F. DONALD (2004): Bird census and survey techniques. In: W. J. Sutherland,, Newton, I., Green, R. E. (eds.): Bird Ecology and Conservation; a Handbook of Techniques. Oxford University Press, Oxford: 17-56.

GREGORY, R. D., A. STRIEN (2010) Wild bird indicators: using composite population trends of birds as measures of environmental health. Ornithological Science 9: 3-22.

GOODENOUGH, A. E., A. S. GOODENOUGH (2012) Development of a Rapid and Precise Method of Digital Image Analysis to Quantify Canopy Density and Structural Complexity. 
International Scholarly Research Network 2012 (ID 619842). Available at: http://dx.doi. $\operatorname{org} / 10.5402 / 2012 / 619842$ (accessed on 02.03.2016).

HAMMER, Ø., D. A. T. HARPER, P. D. RYAN (2001) PAST: Paleontological Statistics Software Package for Education and Data Analysis. Palaeontologia Electronica 4(1): 9.

HORAK, J., S. VODKA, J. KOUT, J. P. HALDA, P. BOGUSCH, P. PECH (2014): Biodiversity of most dead wood-dependent organism in thermophilic temperate oak woodlands thrives on diversity of open landscape structures. Forest Ecology Management 315: 80-85.

HORTON, G. H., W. G. SHRIVER, J. J. BULER (2016) An assessment of spatio-temporal relationships between nocturnal bird migration traffic rates and diurnal bird stopover density. Movement Ecology 4 URL: http://www.ncbi.nlm.nih.gov/pmc/articles/PMC4705634/ (accessed on 01.12.2016).

INGER, R., R. GREGORY, J. P. DUFFY, I. SCOTT, P. VORISEK, K. J. GASTON (2014) Common European birds are declining rapidly while less abundant species' numbers are rising. Ecology letters 2014 (ID 12387).Available at: http://www.seo.org/wp-content/uploads/2014/11/ecologyletters.pdf (accessed on 06.03.2016).

MACGREGOR-FORS, I., L. MORALES-PÉREZ, J. E. SCHONDUBE (2012) From Forests to Cities: Effects of urbanization on tropical birds. Studies in Avian Biology 45: 33-48.

MARTIN, K., A. NORRIN, M. DREVER (2006) Effects of dark beetle outbreaks on avian biodiversity in the British Columbia interior: Implications for critical habitat management. BC Journal of Ecosystems and Management 7 (3): 10-24.

MARTIN-GARCIA, J., L. BARBARO, J. J. DIEZ, H. JACTEL (2013) Contribution of poplar plantations to bird conservation in riparian forests. Silva Fenn 47 URL: http://www.silvafennica.fi/pdf/ article1043.pdf (accessed on 01.12.2016).

MELLES, S., S. GLENN, K. MARTIN (2003) Urban bird diversity and landscape complexity: Species-environment associations along a multiscale habitat gradient. Conservation Ecology 7(1).Available at: http://www.ecologyandsociety.org/vol7/iss1/art5/main.html (accessed on 06.03.2016).

MUNTEANU, C., I. F. GHEORGHE, R. PLĂIAȘU, M. STAN, V. TATOLE, D. MURARIU (2009): Flora și fauna ostroavelor de pe Dunăre. Green Steps, Brașov, 25 pp. (in Romanian)

NOSS, R. F. (1999): Assessing and monitoring forest biodiversity: A suggested framework and indicators. Forest Ecology and Management 2-3: 135-146.

POPRACH, K., J. VRBKOVÁ, I. MACHAR (2015) Detectability as an important factor influencing the knowledge of bird diversity in a floodplain forest ecosystem. Journal of Forest Science 61(3): 89-97.

PUETTMANN, K. J., S. M. WILSON, S. C. BAKER, P. J. DONOSO, L. DRÖSSLER, A. GIRMA, B. D. HARVEY, T. KNOKE, Y. LU, S. NOCETINI, F. E. PUTZ, T. YOSHIDA, J. BAUHUS (2015) Silvicultural alternatives to conventional even-aged forest management - what limits global adoption? Forest Ecosystems 2 URL: https://forestecosyst.springeropen.com/articles/10.1186/ s40663-015-0031-x (accessed on 01.12.2016).

RANJIT DANIELS, R. J., N. V. JOSHI, M. GADGIL (1992) On the relantionship between bird and woody plant species diversity in the Uttara Kannada district of south India. Proceedings of the National Academy of Sciences of the United States of America 89: 5311-5315.

RIJA, A. A., A. S. MGELWA, R. B. MODEST, S. H. HASSAN (2015): Composition and Functional Diversity in Bird Communities in a Protected Humid Coastal Savanna. Advances in Zoology 2015: $1-7$.

SCHÜTZ, J. P. (1999): Close-to-nature silviculture: is this concept compatible with species diversity? Forestry 72: $359-366$.

SIMONS, T. R., S. A. SHRINER, G. L. FARNSWORTH (2006) Comparison of breeding bird and vegetation communities in primary and secondary forests of Great Snoky Mountains National Park. Biological Conservation I(29): 302-311.

SMITH., G. F., S. IREMONGER, D. L. KELLY, S. O’DONOGHUE, F. J. G. MITCHELL (2007) Enhancing vegetation diversity in glades, rides and roads in plantation forests. Biology Conservation 136: 283-294.

SMITH, D. R., C. P. MCGOWAN, J. P. DAILY, J. D. NICHOLS, J. A. SWEKA, J. E. LYONS,(2013): Evaluating a multispecies adaptative management framework: must uncertainty impede effective decision-making? Journal of Applied Ecology 50: 1431-1440.

STEIGER, J., E. TABACCHI, S. DUFOUR, D. CORENBLIT, J. L. PEIRY (2005) Hydrogeomorphic processes affecting riparian habitat within alluvial channel-floodplain river systems: a review... . River Research and Applications 21: 719-737. 
SUBASINGHE, K., A. P. SUMANAPALA, S. R. WEERAWARDHENA (2014) The impact of forest conversion on bird communities in the northern flank of the Knuckles Mountain Forest Range, Sri Lanka. Journal of Asia-Pacific 7: 367-373.

SWEENEY, O. F. M., M. W. WILSON, S. IRWIN, T. C. KELLY, J. O'HALLORAN (2010) The influence of a native tree species mix component on bird communities in non-native coniferous plantations in Ireland. Bird study: 483-494.

SYMONDS, M. R. E., C. N. JOHNSON (2008) Species Richness and Evenness in Australian Birds. The American Naturalist 171(4): 480-490.

TEMPLE, S. A., J. A. WIENS (1989) Bird populations and environmental changes: can birds be bioindicators. American Birds 43(2):260-270.

THOMPSON, I., B. MACKEY, S. MCNULTY, A. MOSSELER (2009) Forest resilience, biodiversity, and climate change. A synthesis of the biodiversity/resilience/stability relationship in forest ecosystems. Secretariat of the Convention on Biological Diversity, Montreal, Canada. Technical Series no. 43, 67 pp.

WINKLER, D., Á. ERDÖ (2012) A comparative study of breeding bird communities in representative habitats of the Sárosfö Nature Reserve area. Natura Somogyiensis 22: 213-222. 